Research, part of a Special Feature on Ecosystem Services, Governance and Stakeholder Participation

\title{
Reducing Emissions from Deforestation and Forest Degradation (REDD+): Transaction Costs of Six Peruvian Projects
}

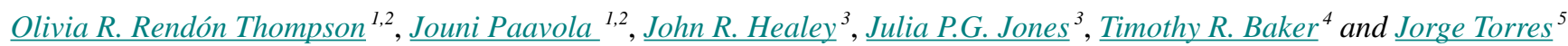

\begin{abstract}
Reduced Emissions from Deforestation and Forest Degradation (REDD+) has received strong support as a major component of future global climate change policy. The financial mechanism of REDD+ is payment for the ecosystem service of carbon sequestration in tropical forests that is expected to create incentives for conservation of forest cover and condition. However, the costs of achieving emissions reduction by these means remain largely unknown. We assess the set-up, implementation, and monitoring costs, i.e., collectively the transaction costs, of six of the first seven REDD+ project designs from the Peruvian Amazon and compare them with established projects in Brazil and Bolivia. The estimated costs vary greatly among the assessed projects from US $\$ 0.16$ to 1.44 ha- $1 \mathrm{yr}-1$, with an average of US $\$ 0.73$ ha- $1 \mathrm{yr}-1$, though they are comparable to earlier published estimates. The results indicate that the costs of implementing REDD+ are highly uncertain for participating developing countries because of issues such as inadequate project design and how additionality is determined. Furthermore, some insight is obtained into how different activities to reduce deforestation and forest degradation, the type of implementer, and project location affect implementation costs of REDD+ projects. Even with these first estimates, the cost of preserving existing intact forests in the Peruvian Amazon may have been underestimated.
\end{abstract}

Key Words: additionality; Amazon; Peru; REDD+; set-up, implementation, and monitoring costs; transaction costs

\section{INTRODUCTION}

Reducing Emissions from Deforestation and Forest Degradation (REDD+) is an international program for protecting and enhancing the carbon stocks of tropical forest regions and reducing anthropogenic emissions of greenhouse gases (Angelsen et al. 2009, UNFCCC 2011). Initially adopted at the 13th Conference of Parties (COP) of the United Nations Framework Conference on Climate Change (UNFCCC) in 2007 (Thompson et al. 2011), and further developed at the UNFCCC COP16 in Cancun, Mexico in 2010 (UNFCCC 2011), the rationale of REDD+ is to reduce greenhouse gas emissions by incentivizing a net reduction in tropical deforestation and forest degradation. The measures can include conservation, sustainable management, and the enhancement of the carbon stocks of existing forests to provide positive incentives in countries where forests are better protected, as well as those where deforestation and forest degradation rates are high (Thompson et al. 2011). It is intended that REDD+ activities align with ongoing efforts to improve forest management, and to ensure the achievement of cobenefits such as poverty alleviation, watershed protection, and biodiversity conservation.

One of the key debates surrounding the development of REDD+ relates to the costs of implementing policies and actions to achieve these aims; cost estimates are particularly important for tropical forest countries to inform decisions on how and where to establish projects. Opportunity costs, i.e., the potential benefits of alternative land uses that have to be forsaken when forest is conserved, are generally considered to be the largest cost component of REDD+ and they are used in global and regional estimates of REDD+ costs. Kindermann et al. (2008) estimate that the global opportunity cost of reducing deforestation rates by 50\% in Latin America by 2030 would be US $\$ 10-25 / \mathrm{tCO}_{2}$ and that of a $10 \%$ reduction would be US\$1.5-8/tCO . These global estimates are based on the opportunity costs of large-scale, commercial agriculture such as soy bean cultivation. Opportunity costs of small-scale, subsistence agriculture are often much smaller: Grieg-Gran (2006) found that in eight tropical countries farming income equates to less than US\$1/tCO $\mathrm{CO}_{2}$ where land has been recently converted from forest, and is usually well below US $\$ 5 / \mathrm{tCO}$. This is similar to estimates of Potvin et al. (2008) who calculated opportunity costs of US $\$ 1.11 / \mathrm{tCO}_{2} \mathrm{e}$ for small-scale cattle ranching in Panama.

Although opportunity costs are critical in the assessment of REDD+ and other conservation projects, they are only a part of the story. The set-up, implementation, and monitoring costs of REDD+ projects may also form a significant portion of total project costs (Sommerville et al. 2009, 2011, Baker et al. 2010). For example, in remoter areas the opportunity costs of forest conversion may be smaller than the transaction and implementation costs (White and Minang 2011), and in the case of (de jure) free-access forests, opportunity costs may approach zero because conserving these forests may only involve the costs of modifying current patterns of forest use (Pagiola and Bosquet 2009). Even where opportunity costs are significant, the costs of establishing, implementing, and monitoring may make an important contribution to total

\footnotetext{
${ }^{1}$ Centre for Climate Change Economics and Policy (CCCEP), ${ }^{2}$ Sustainability Research Institute, School of Earth and Environment, University of Leeds, ${ }^{3}$ School of Environment, Natural Resources and Geography, Bangor University, ${ }^{4}$ School of Geography, University of Leeds, ${ }^{5}$ Sustainable Forestry Management Ltd. and Bosques Amazónicos (SFM-BAM S.A.C)
} 
Table 1. Definition of cost categories of REDD+ projects in this study.

\begin{tabular}{|c|c|c|}
\hline Cost Categories & Definition & Inclusion \\
\hline Opportunity costs & $\begin{array}{l}\text { Costs resulting from the forgone benefits that deforestation } \\
\text { would have generated for livelihoods and the national economy. }\end{array}$ & Not included. \\
\hline Set-up costs & $\begin{array}{l}\text { Costs necessary for the implementers to establish or start a } \\
\text { REDD+ project, taking it from design to implementation. }\end{array}$ & $\begin{array}{l}\text { Information search and design (e.g., carbon stocks, } \\
\text { deforestation modeling, socioeconomic characteristics), } \\
\text { negotiation, certification, capacity-building, } \\
\text { procurement, etc. }\end{array}$ \\
\hline Implementation costs & $\begin{array}{l}\text { Costs directly associated with the actions leading to reduced } \\
\text { deforestation or forest degradation, and hence to reduced } \\
\text { emissions. }\end{array}$ & $\begin{array}{l}\text { Fire management programs, patrolling, administrative } \\
\text { costs, promoting alternative sustainable livelihoods, } \\
\text { sustainable forestry management, community } \\
\text { development, etc. }\end{array}$ \\
\hline Monitoring costs & $\begin{array}{l}\text { Costs necessary for the implementers of a REDD+ project to } \\
\text { determine if a certain amount of emissions reduction has been } \\
\text { achieved; as well as other cobenefits. }\end{array}$ & $\begin{array}{l}\text { All activities involved in monitoring carbon stocks, } \\
\text { deforestation and forest degradation, and environmental } \\
\text { and social cobenefits. }\end{array}$ \\
\hline
\end{tabular}

project costs, thus influencing the likely success of the project and its ability to invest significantly in social or biodiversity cobenefits.

There have been a number of attempts to evaluate the implementation costs of REDD+ projects. Boucher (2008) estimated the sum of the average implementation, administration, and transaction costs from three different REDD+ projects to be US $\$ 1 / \mathrm{tCO}_{2}$ (range US $\$ 0.01$ - 1.23/ $\mathrm{tCO}_{2}$ ), and Börner and Wunder (2008) estimated a comparable cost range of US $\$ 0.08-0.30 / \mathrm{tCO}_{2}$ for the state of Mato Grosso, Brazil. However, data remain extremely sparse given the large number of emerging REDD+ projects in tropical forest regions. Implementation costs are likely to vary with the scale and scope of agreed contracts, the nature of participating entities, carbon pools covered, activities adopted for reducing deforestation and/or forest degradation, and monitoring methods employed (GFC and CEESP 2008) but current data do not allow even a preliminary evaluation of these issues. Indeed, the literature does not even have a consistent unambiguous method for defining and classifying forest and carbon project costs (Cacho et al. 2003). For example, some authors consider set-up, implementation, and monitoring costs as only one part of administration or transaction costs (Cacho et al. 2005, Grieg-Gran 2006, Cacho and Lipper 2007, Börner and Wunder 2008), whereas others such as Angelsen (2008) and Viana et al. (2009) consider contract negotiation expenses to be the sole transaction costs.

We examined the costs associated with the establishment of six REDD+ projects in the Peruvian Amazon being operated under voluntary standards. Voluntary local projects are pioneers in REDD+ implementation that will inform future compliance programs. In this light, our analysis of six Peruvian REDD+ pilot projects aims to contribute to a better understanding of the cost of local forest-based initiatives for emissions reduction and REDD+. We examine the project setup, implementation and monitoring costs of the Peruvian projects and compare them with the established REDD+ projects of Juma in Brazil and Noel Kempff in Bolivia. Peru is a particularly important place to study these initiatives because it has a large area of forest potentially eligible under REDD+ schemes: Peru has the second largest area (9\% or $667,244 \mathrm{~km}^{2}$ ) of the Amazon, with $90 \%$ of its original forest cover remaining (UNEP and ACTO 2009). However, economic activities and development plans such as the Interoceanic highway in Madre de Dios (ACA and ACCA 2008), gold mining (Mosquera et al. 2009), oil and gas exploration (Finer and Orta-Martínez 2010), agriculture, and timber extraction threaten Peru's historically low deforestation rate (UNEP and ACTO 2009, Verweij et al. 2009). As a result, in recent years the Peruvian government has established and extended protected areas and indigenous territories in the Peruvian Amazon (Anke et al. 2008). In addition, more than 12 REDD+ projects have been proposed by different NGOs and commercial organizations (Hajek et al. 2011).

\section{MATERIALS AND METHODS}

For the purposes of this study, we define set-up costs to include primarily the costs of obtaining information, procurement, scheme design, negotiation, and certifying emission reductions (Table 1). Implementation costs arise from activities reducing deforestation or forest degradation such as enforcement and forest protection, which aim to ensure additionality, and administrative costs associated with them. Finally, monitoring costs include the costs of monitoring carbon stocks, deforestation and forest degradation, and cobenefits, to assess conditionality. These three costs, i.e., setup, implementation, and monitoring, will hereafter be jointly referred to as transaction costs. The cost categories used here are adapted from Pagiola and Bosquet (2009) and White and Minang (2011). The cost data only include costs incurred or planned by project developers or investors, not those incurred by third parties such as the government. We acknowledge that validation and verification costs depend on the project area, location, distribution of locations meriting a field visit, and 
also on any discounts provided for bundled projects (Jorge Torres, Bosques Amazónicos, personal communication). Our data are derived from the most relevant sources for this region. Thus, the cost we use for validating the projects with an international standard, Climate, Community and Biodiversity Standard (CCB) or the Voluntary Carbon Standard (VCS), is US $\$ 32,400$, based on the average of the Tambopata National Reserve and Bahuaja Sonene National Park (TBNP) project's existing estimate (US\$35,000) and those of two other Peruvian projects (US\$33,000 and US\$29,200, respectively) not included in this study (Jorge Torres, Bosques Amazónicos, personal communication). Furthermore, the cost of modeling future deforestation for TBNP, necessary for project design, was estimated by the expert who carried out the deforestation model for the region of Madre de Dios where TBNP is located (Lucio Pedroni, Carbon Decisions, personal communication); this is the only company performing this kind of modeling service in Peru.

We analyzed a mix of primary and secondary materials, including quantitative data from project developers' budgets, qualitative interviews with them, and project documents. The six projects examined (Fig. 1) were the only pilot REDD+ projects in Peru at the time, except for one project, which declined to participate in our study. The material was collected during April - July 2009 and updated during August November 2011. Project developers were identified through contacts and web searches, and included five NGOs and one private company. Project costs, incurred and planned ( 50\% of data is incurred costs and the rest planned), were queried with a contact person from each project and the initial request was followed by e-mail exchanges and meetings to clarify, complete, and verify the data and to understand the background of each project.

The six Peruvian pilot projects are being developed in a wide range of different land use designations: protected areas, indigenous lands, forestry concessions, and conservation concessions. We compared the costs of these projects with those of two established Amazonian REDD+ projects: the Noel Kempff Climate Action Project in Bolivia and Juma Sustainable Development Reserve RED Project in Brazil (Table 2).

The cost data of the six Peruvian projects were available for different time periods, ranging from two to seven years, so it was necessary to standardize them to a common period. We selected a 20-year period because four out of the six Peruvian projects have a 20-year timeline and it facilitated comparison with the longer term projects of Noel Kempff and Juma. We calculated average annual set-up, implementation, and monitoring costs and their sum as transaction costs in US\$ per hectare over the 20-year period. When calculating the net present value (NPV) of transaction costs, we used the discount rates of 3.8\% (Central Bank of Peru's annualized interest rate for December 2010), 5\%, and $10 \%$ to maintain comparability with similar studies (Pinedo-Vasquez et al. 1992, Ferraro 2002, van Kooten et al. 2004, Nepstad et al. 2007, Potvin et al. 2008, Viana et al. 2009) and following recommendations in the literature for South American countries (Howard et al. 1996, Rondon et al. 2010).

Fig. 1. Location of the six Peruvian REDD+ pilot projects. Tambopata National Reserve and Bahuaja Sonene National Park (TBNP); Sustainable Forest Management in Native Communities (SFM-NC); Cordillera Azul National Park (CANP); Alto Huayabamba Conservation Concession (AHCC); Los Amigos Conservation Concession (LACC); Sustainable Forest Management in Forestry Concessions (SFM-FC). Map provided by R. M. Roman.

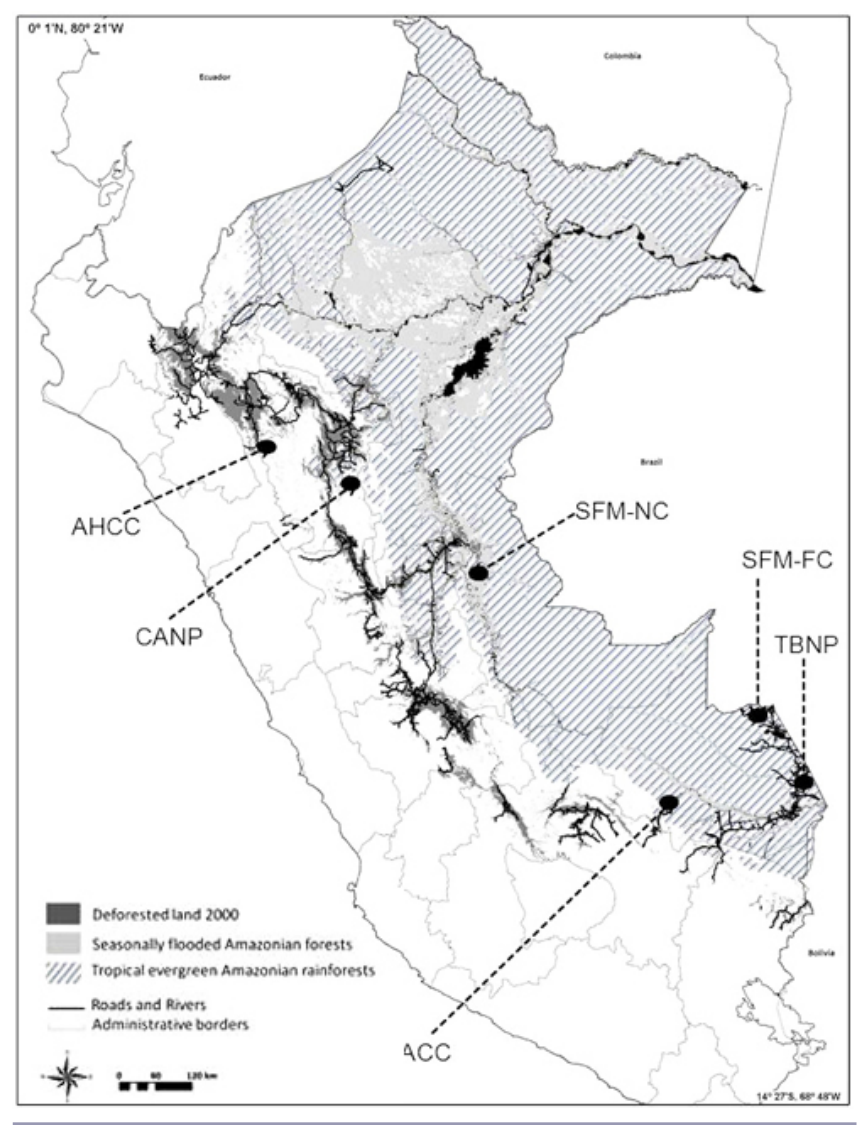

To facilitate comparisons between projects, we calculated costs on a per hectare basis. In addition, to provide values comparable with estimates of opportunity costs, we calculated the cost of reducing $1 \mathrm{tCO}_{2}$ emissions for the two Peruvian projects with the most complete data on costs and estimated emission reductions (TBNP and SFM-FC; acronyms explained in Fig. 1), and compared them with the Juma and the Noel Kempff projects. These calculations show which of these projects is most cost-effective at reducing emissions from deforestation and forest degradation. 


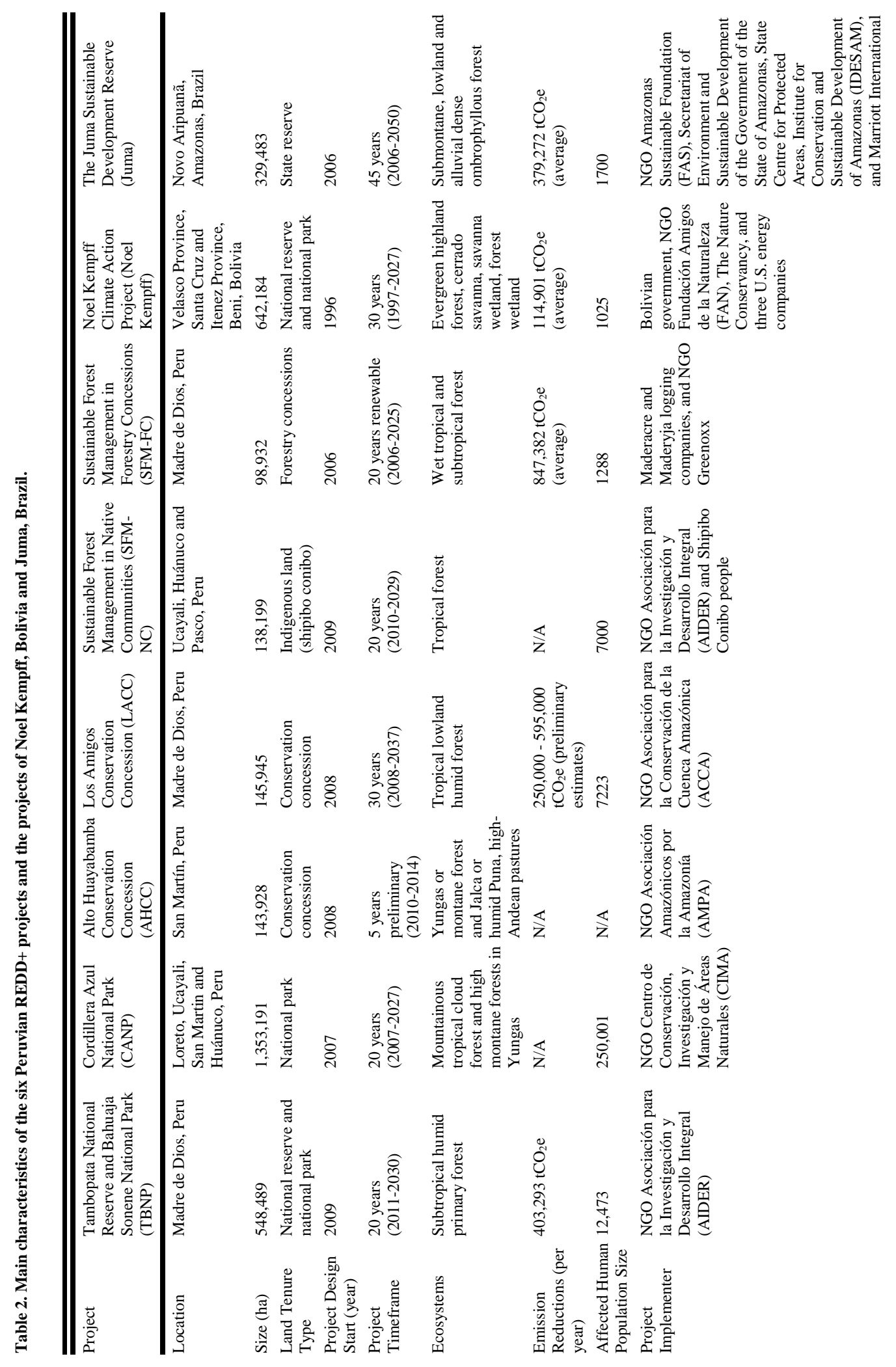




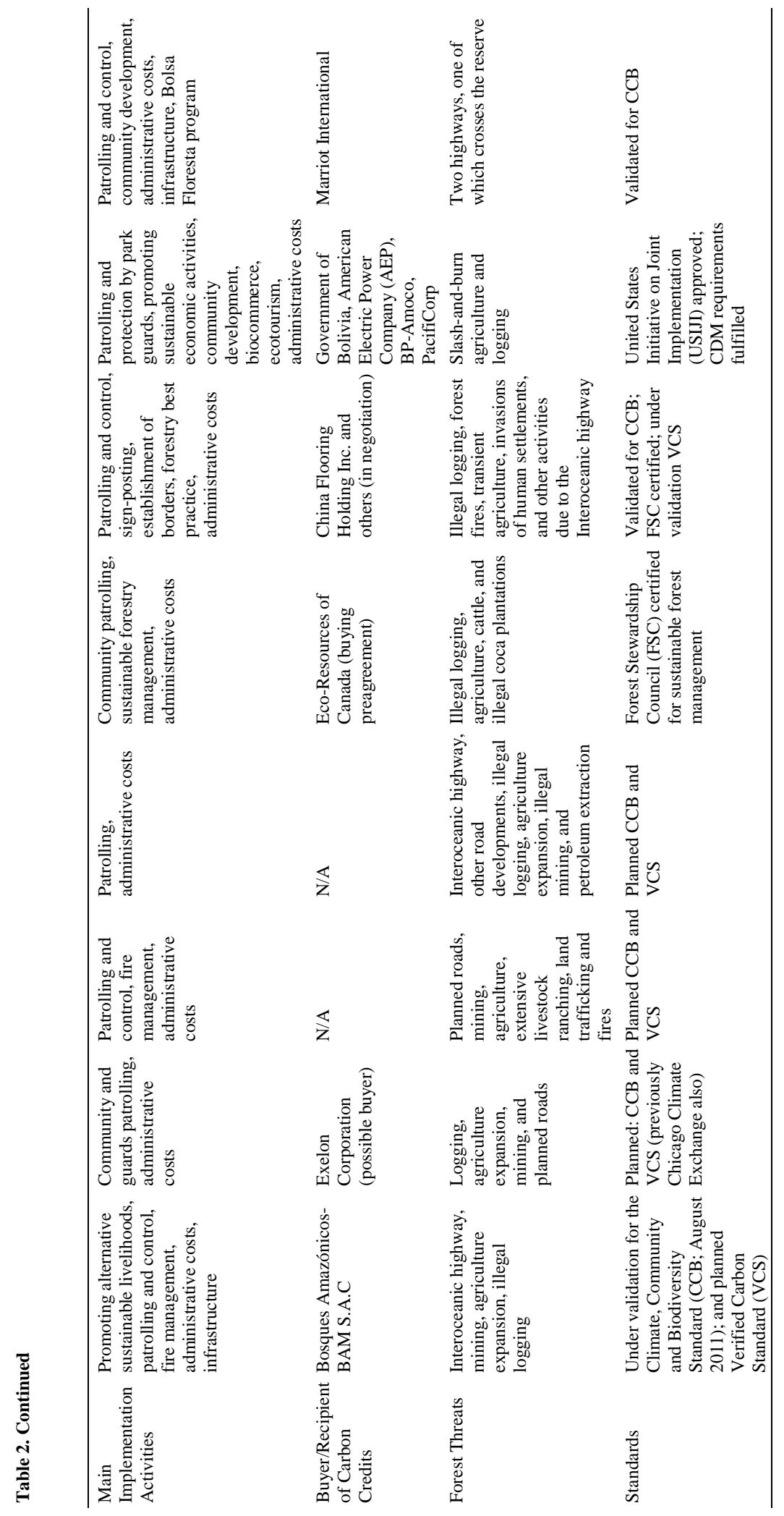




\section{RESULTS}

The 20-year REDD+ project budgets vary from US\$0.16 to $1.44 \mathrm{ha}^{-1} \mathrm{yr}^{-1}$, with an average of US\$0.73 $\mathrm{ha}^{-1} \mathrm{yr}^{-1}$, when they are expressed as average transaction costs per project forest area. There was no evidence of a general negative correlation between these costs and total project area. However, in line with economies-of-scale reasoning, one of the projects with a small forest area, SFM-NC, was the most costly (Fig. 2). LACC and AHCC, which also had below-average forest area, had the lowest cost per hectare but this could be because of incomplete data owing to ongoing project development. The SFM-FC and Juma projects may also be underestimating their project costs, as has been observed by other authors for pilot REDD+ projects (e.g., Chenost et al. 2009). The intermediatelevel costs of the TBNP project are comparable with those of the similarly sized Noel Kempff project.

Fig. 2. Average transaction costs of the six Peruvian projects (discounted at 3.8\%), the Brazilian and Bolivian REDD+ projects in relation to project area (diamonds $=$ protected areas; triangles = conservation concessions; circle $=$ forestry concession; square $=$ indigenous land). Project acronyms are defined in Figure 1.

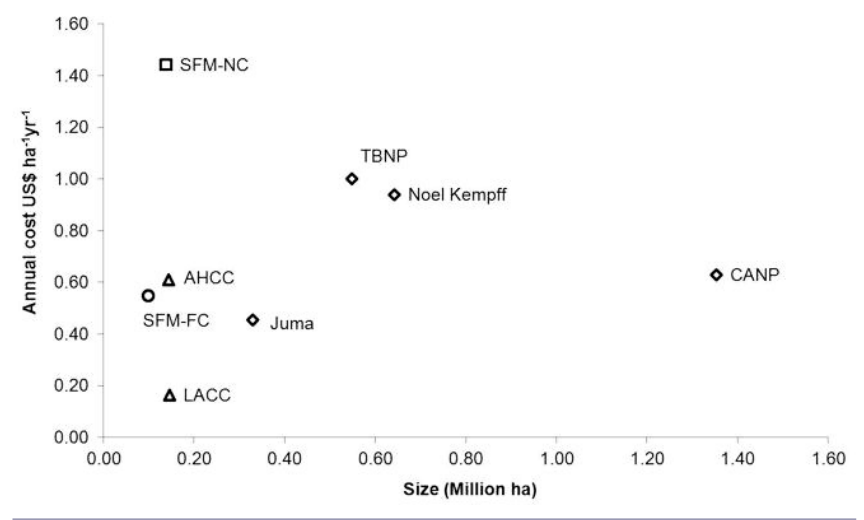

On average about $10 \%$ of the total transaction costs were due to set-up (Standard Error [SE] =3.07), 20\% due to monitoring $(\mathrm{SE}=7.52)$, and $70 \%$ due to implementation ( $\mathrm{SE}=7.54$; Table $3)$. There were no systematic differences between the six Peruvian projects and the two established projects in Bolivia and Brazil, though the mean set-up cost of the Peruvian projects was lower. Monitoring costs of the Peruvian projects ranged widely from 0 to $66 \%$; however for three of the projects (TBNP, CANP, and AHCC) they ranged between 14 and 25\%, which is within the range of the established Bolivian and Brazilian projects. TBNP and AHCC were the only two projects to include forest carbon, deforestation, social and environmental monitoring. In all the Peruvian projects except for SFM-FC, over $70 \%$ of the costs were due to implementation. Although implementation planning was still underway in the Peruvian projects, some observations can be made about implementation costs. One of the smallest projects, SFM-NC, had the highest projected average annual implementation cost, US\$1.26 per hectare. The TBNP and the Noel Kempff projects had a similar intermediate size and were also closely matched in implementation cost.

Four of the Peruvian projects included planned monitoring costs in their budget. We compare them in Figure 3 with published costs of eight different monitoring methods and technologies. The costs reported by all four projects were in the middle of the range of the methods/technologies (higher than four and lower than the other four). These costs are likely to increase, depending on whether only deforestation is monitored, or both deforestation and degradation.

Fig. 3. Average monitoring costs per hectare per year for four Peruvian REDD+ projects (black) and eight commonly used monitoring methods/technologies (grey): OMRS = Optical Medium Resolution Sensor, Landsat-5, TM; NFMA = National Forest Monitoring and Assessment for five countries; OHRS = Optical High Resolution Sensor, Quickbird; GBI (B) = Ground-based inventories, Noel Kempff, Bolivia; OVHRS = Optical Very High Resolution Sensor, Quickbird and Worldview-1; Indonesia (A) = Airborne monitoring, Ulu Masen Project, Indonesia; LiDAR = airborne Light Detection and Ranging, Indonesia (data from Böttcher et al. 2009 in which the primary source references are cited).

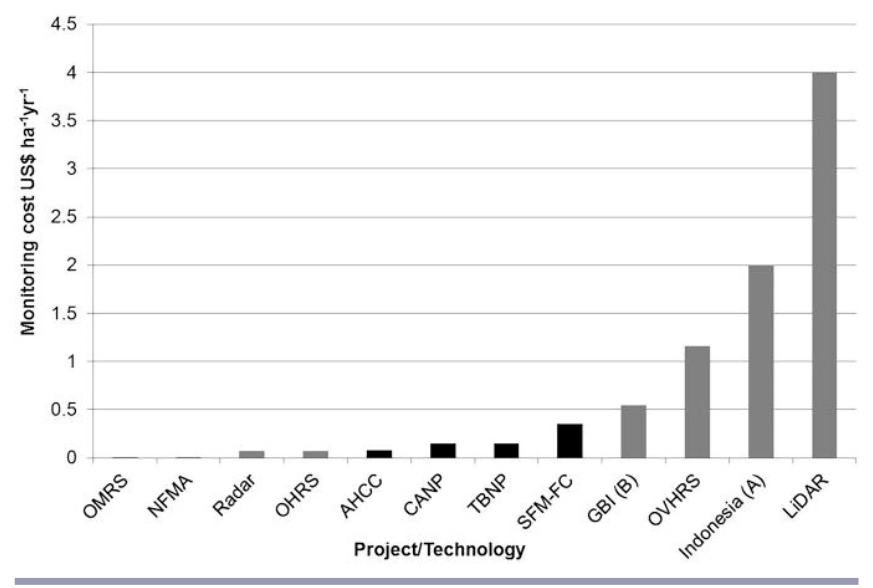

\section{DISCUSSION}

Our estimate of the average transaction cost of the six Peruvian REDD+ projects (US\$0.73 $\mathrm{ha}^{-1} \mathrm{yr}^{-1}$; $\mathrm{SE}=0.18$ ) is somewhat lower than previously published costs. For example, GriegGran (2006) estimated the annual administration costs for REDD+ in eight tropical countries to be between US\$4 and 15 per hectare, and Börner and Wunder (2008) estimated annual implementation costs of US\$4.5 per hectare for REDD+ projects in the Brazilian Amazon. Slightly closer to 
Table 3. Summary of estimated costs for the six Peruvian projects and the actual costs of two established projects in Bolivia and Brazil, including: set up, implementation, and monitoring costs annually per hectare and as a percentage of the total; projects' total annual transaction cost per hectare at 3.8\%,5\%, and 10\% discount rate; total annual transaction cost in US\$; and estimated cost of reducing $1 \mathrm{tCO}_{2}$ emissions for two projects in Peru compared with the two established projects in Bolivia and Brazil. Note that all values are reported as average net present value discounted at 3.8\% (unless otherwise stated). The data for the Bolivian and Brazilian projects was obtained from Brown et al. 2000, Asquith et al. 2002, FAS 2008, and Brown 2005. Project acronyms are defined in Figure 1.

\begin{tabular}{|c|c|c|c|c|c|c|c|c|c|c|}
\hline \multirow{2}{*}{\multicolumn{2}{|c|}{ Cost component }} & \multicolumn{9}{|c|}{ Project } \\
\hline & & TBNP & CANP & AHCC & LACC & SFM-NC & SFM-FC & $\begin{array}{c}\text { Peruvian } \\
\text { Project } \\
\text { Mean }(\%)\end{array}$ & $\begin{array}{c}\text { Noel } \\
\text { Kempff }\end{array}$ & Juma \\
\hline \multirow{2}{*}{\multicolumn{2}{|c|}{$\begin{array}{l}\text { Set-up costs } \\
\text { (US\$ ha }^{-1} \mathrm{yr}^{-1}[\%] \text { ) }\end{array}$}} & 0.06 & 0.04 & 0.04 & 0.06 & 0.18 & 0.08 & 0.08 & 0.21 & 0.11 \\
\hline & & (4) & (5) & (5) & (28) & (9) & (11) & (10) & (18) & $(20)$ \\
\hline \multicolumn{2}{|c|}{ Implementation costs } & 0.79 & 0.43 & 0.49 & 0.11 & 1.26 & 0.12 & 0.53 & 0.64 & 0.22 \\
\hline \multicolumn{2}{|l|}{ (US\$ $\left.\mathrm{ha}^{-1} \mathrm{yr}^{-1}[\%]\right)$} & (81) & $(70)$ & $(81)$ & (72) & (91) & (23) & (70) & (72) & $(52)$ \\
\hline \multicolumn{2}{|l|}{ Monitoring costs } & 0.15 & 0.15 & 0.08 & 0 & 0 & 0.35 & 0.12 & 0.09 & 0.12 \\
\hline \multicolumn{2}{|l|}{ (US\$ ha $\left.{ }^{-1} \mathrm{yr}^{-1}[\%]\right)$} & (15) & (25) & (14) & (0) & (0) & (66) & (20) & (10) & $(28)$ \\
\hline \multirow{3}{*}{$\begin{array}{l}\text { Total transaction } \\
\operatorname{cost}\left(\mathrm{US} \$ \mathrm{ha}^{-1} \mathrm{yr}^{-1}\right)\end{array}$} & At $3.8 \%$ discount rate & 1.00 & 0.63 & 0.61 & 0.16 & 1.44 & 0.55 & 0.73 & 0.94 & 0.46 \\
\hline & At $5 \%$ discount rate & 0.90 & 0.57 & 0.55 & 0.15 & 1.31 & 0.50 & 0.66 & 0.86 & 0.41 \\
\hline & At $10 \%$ discount rate & 0.62 & 0.40 & 0.38 & 0.11 & 0.94 & 0.36 & 0.46 & 0.63 & 0.29 \\
\hline \multicolumn{2}{|c|}{ Annual transaction cost (US\$) } & 549,068 & 851,719 & 87,865 & 24,031 & 199,269 & 54,252 & 294,367 & 603,186 & 149,975 \\
\hline \multicolumn{2}{|c|}{ Cost per emissions reduction (US $\$ / 1 \mathrm{tCO}_{2}$ ) } & 1.36 & N/A & N/A & N/A & N/A & 0.06 & 0.71 & 5.25 & 0.40 \\
\hline
\end{tabular}

our estimates are those of the PROFAFOR Ecuadorian reforestation and afforestation project that had annual per hectare costs of US\$3 (Wunder and Alban 2008), as did the Costa Rican national payment for ecosystem services scheme (Grieg-Gran 2006). In contrast, if we look at one category of costs of the Peruvian projects, the implementation costs (US\$0.11 - 1.26), these are in the range found by Bruner et al. (2004) for actual average annual expenditure for terrestrial protected areas (US\$0.05 - 3.00). However, these costs are clearly below what Oestreicher et al. (2009) considered the ideal funding (US\$7.09) to accomplish the management plan objectives in protected areas in Panama.

A variety of factors might contribute to the low costs that we report here compared with other published values. First, some of our costs are initial estimates rather than the actual costs incurred by the project developer, and such costs may prove to be an underestimate. However, although planned costs may not be as accurate as incurred costs, they are still important for examining REDD+ developers' intervention strategies. Furthermore, care was taken to ensure that any estimates used in this study were based on locally relevant values.

\section{Monitoring costs: what and how}

Second, patchy inclusion of monitoring costs in project budgets suggests that project developers may not be fully aware of the efforts and expenditure needed to monitor carbon stocks, reduction of emissions, and cobenefits in a REDD+ project. Monitoring costs will depend on the desired level of accuracy, which may vary by the type of project activity and thus on the technology selected, whether only deforestation is monitored, or deforestation and degradation (the latter is much more challenging and potentially costly), the size of the project area, e.g., per hectare costs of LiDAR coverage may be significantly reduced if a large area is to be surveyed (Asner 2009), whether the project area is contiguous or dispersed among small landowners, the natural variation within the various carbon pools, and the terrain of the landscape (IPCC 2000, Böttcher et al. 2009). In particular, in these case studies, project developers did not consider cost differences between monitoring only deforestation, or deforestation and degradation; to monitor forest degradation it is necessary to combine high resolution satellite imagery with ground monitoring (Böttcher et al. 2009, Corbera et al. 2010) though airborne LiDAR offers considerable potential to improve the efficiency once its costs have reduced sufficiently (Asner 2009). Furthermore, some of the variability in costs between different projects may be related to their size; monitoring costs are likely to represent a smaller percentage of total costs in larger projects (Mooney et al. 2004). This is true even when monitoring includes social and environmental cobenefits, and not just carbon stocks, deforestation, and forest degradation.

Third, although social and environmental cobenefits feature prominently in the policy surrounding REDD+ and are considered to be criteria for project approval, the huge challenges in their implementation and monitoring do not seem to have been considered fully in the design of the projects assessed in this study. For example, at the time of data collection most of the Peruvian project developers were unsure of what compensation, if any, would be given to local inhabitants. This is evidence of the high risk that these projects 
are underestimating or overlooking the costs of ensuring social and environmental cobenefits. Again, this may mean that costs will rise as these REDD+ projects develop.

\section{Implementation costs: reducing deforestation and forest degradation}

In addition to the generally low costs in Peru that we find in this study, there is also considerable variability between the projects. This variability may be related to the characteristics of the projects themselves such as differences in implementation activity portfolios, as well as the history of project areas and affected human population size. Our data provide some evidence of the planned activities and factors that might be most influential in determining implementation costs. For example, the SFM-FC project managed by private logging companies had the second lowest implementation costs and the smallest affected population size. This project planned to enforce existing best practice in forestry, as well as adding patrolling and border definition. Likewise, at the time of the study, the LACC project, which had the lowest implement costs, did not consider any activities involving local inhabitants. Furthermore, of the REDD+ projects considered, SFM-FC and LACC are in the most remote locations where there are likely to be less intense pressures of deforestation and forest degradation. On the other hand, the TBNP project, with the second highest implementation costs, had a higher affected population size and a more varied portfolio of activities promoting sustainable alternative livelihoods, patrolling, building and maintaining infrastructure, and fire management. The SFM-NC project, with the highest implementation costs, also involved community-based activities for sustainable forestry management. Thus, there seems to be a link between low project implementation costs and a lack of activities aimed at local sustainability and location in more remote areas. In addition, further research is needed to examine if private company-based and NGO-based REDD+ projects are, in general, less costly per hectare than community-based projects.

The ratio of implementation costs to emissions reduction potential is a measure of the 'cost-effectiveness' of REDD+ projects (Pagiola and Bosquet 2009). This ratio can also be used to compare estimates of the opportunity costs of similar projects and to judge the importance of implementation costs for achieving project aims. Our results suggest that the ratio of implementation costs to emissions reduction potential is generally low: for the two Peruvian projects with definite estimates of future emission reductions and the established projects in Bolivia and Brazil, the calculated implementation costs per $\mathrm{tCO}_{2}$ emissions reduction range from US $\$ 0.06$ to 5.25 , with a mean of US\$1.77 (Table 3). These values are within the range of estimates of opportunity costs from other Amazonian studies, but at the lower end. For example, Vera Diaz and Schwartzman (2005) calculated that logging and cattle ranching benefits in Brazil translate to about $\mathrm{US} \$ 3 / \mathrm{tCO}_{2}$ where there is high timber potential and to about US\$0.8/tCO where timber potential is low. Nepstad et al. (2007) found an average opportunity cost of US\$1.6/tCO $\mathrm{CO}_{2} \mathrm{e}$ for the Brazilian Amazon. Börner and Wunder (2008) found that opportunity costs vary across and within states in Brazil, from US $\$ 3 / \mathrm{tCO}_{2}$ in Amazonas and up to $\mathrm{US} \$ 12 / \mathrm{tCO}_{2}$ in Mato Grosso, and Armas et al. (2009) found that the opportunity cost for the Peruvian Amazon varied among provinces, from US\$0.6/ha in San Martin up to US\$67/ha in Amazonas, with an average opportunity cost of US\$4.4/ha. These values suggest that opportunity costs are likely to exceed transaction costs, which are dominated by implementation costs, for the majority of projects.

Uncertainty in per-hectare costs is compounded in estimates of the ratio of implementation costs to expected emissions reductions, by uncertainty in estimates of current carbon stocks and deforestation threat. For example, the much lower estimated cost of reducing $1 \mathrm{tCO}_{2}$ emissions by the SFM-FC project, US $\$ 0.06 / \mathrm{tCO}_{2}$, is attributable to its very optimistic predictions of total emission reductions (annual average of $847,382 \mathrm{tCO}_{2} \mathrm{e}$ emission reductions). In general, the experience of the Noel Kempff project, where estimates of carbon emissions reductions have periodically been revised downward (Densham et al. 2009), suggests that these values may fall, and therefore cause a rise in the ratio of implementation costs to emissions reductions as projects develop. Together with the expected rise in both implementation and monitoring costs beyond the planned estimates, as projects are implemented, lower achieved emissions reductions than initial overly optimistic estimates are likely to contribute to a large increase in the actual cost of projects per emissions reduction achieved.

\section{Cost of reducing deforestation in the Peruvian Amazon}

Although the costs presented here are uncertain and may be revised upward as projects are implemented, these values provide some of the first data that can be used to estimate the potential cost of implementing an effective REDD+ scheme in the Peruvian Amazon. For comparison, the Peruvian Ministry of the Environment has stated that Peru would need US\$25 million per annum over the next decade to halt deforestation of the 54 million ha of the country's intact natural forest, based on the protection of $32 \%$ of this area in national parks, $22 \%$ in indigenous lands, $39 \%$ in sustainable forestry areas, and $7 \%$ in eco-tourism areas (Painter 2008). The pilot REDD+ projects we examined encompass a similar range of land use designations, i.e., protected areas, indigenous land, forestry concessions, and conservation concessions. Multiplying the project implementation costs (these costs are used because they are the costs of specific activities necessary to achieve reduction of deforestation and forest degradation) estimated in this study by the total area of forest to be protected in the Peruvian Amazon to achieve the Ministry of the Environment's target suggests that its program would cost US\$29 million per annum based on the mean implementation cost of US $\$ 0.53 /$ ha of all six projects. The estimated total cost 
varies from only US\$6 million per annum using the lowest implementation cost of US\$0.11/ha of the LACC project, to US\$68 million per annum if the highest implementation cost of US $\$ 1.26 /$ ha of the SFM-NC project is used. Therefore, the Peruvian Ministry of the Environment's cost estimate is similar to, but slightly below, the average for the six projects reported in this study and 65\% lower than our higher bound estimate.

Comparing the Ministry of the Environment's estimate of the cost of halting deforestation with the wider literature, it falls within the very broad management cost range for protected areas in high wilderness (US\$0.54 - 32.4 million per year) calculated from per-hectare cost estimates reported by Balmford et al. (2003). However, it is well below the range of US\$70.2 - 2700 million per year calculated from the perhectare management cost range for protected areas in densely settled regions by Balmford et al. (2003), which could be more relevant to Peru because of its wide range of forest-use types and deforestation drivers. The estimates of Bruner et al. (2004) also give a range of management costs (US \$48.6 - 486 million) that are much higher than the Peruvian Ministry's estimates. As noted above, through comparison with values from the literature we consider that there is a high risk that the estimated project costs reported in the present study will be underestimates of the actual project implementation costs.

A further reason for considering the cost estimates of the present study as an underestimation across the whole of the Peruvian Amazon is that they are based on public lands, except for the SFM-NC project on indigenous land, and are subject to existing formal legal obligations for conservation or sustainable management. Additional transaction costs required to prevent deforestation and forest degradation are likely to be higher in nonprotected areas. The issue is whether the existing legal designation of these lands is an absolute barrier to demonstrating additionality, or whether a project designed to increase the effectiveness of the existing level of achievement of de jure forest protection could qualify (Healey et al. 2000, Pistorius et al. 2010). Indigenous land could benefit from further incentives to reduce deforestation and forest degradation, which the government seems to be pursuing already through a policy to compensate indigenous people (see Pagarán a indígenas por la conservación ... 2009). However, further incentivizing those entities already voluntarily managing public sites, i.e., protected areas and concessions, may not be economically gainful for a country. On the other hand, evidence shows that tropical countries' efforts to tackle deforestation and forest degradation through designation of conservation areas and promotion of sustainable forest management are not always effective (e.g., Adams et al. 2004, Htun et al. 2010). Frequently this is because forests have been used as open-access resources by local communities and other groups (Börner and Wunder 2008), as seen in national parks and indigenous and extractive reserves in Peru. Therefore, we suggest that our upper-bound estimate of US\$68 million per year to halt deforestation is likely to be closest to representing the actual costs of protecting the forests of the Peruvian Amazon because this estimate corresponds with the lower bounds of relevant management cost ranges reported by Balmford et al. (2003) and Bruner et al. (2004).

To a government, as well as to other actors who are involved in developing REDD+ projects, the cost of reducing deforestation or forest degradation may appear to consist only of the cost of changing the open access status of a forest area. However, the opportunity costs borne by local people cannot be ignored; in many situations they have been using the forests as an important part of their livelihoods and have to forgo this use when forest management changes as a result of the implementation of a REDD+ project. Both formal legal status and reality have to be taken into account before a payment for ecosystem services scheme, such as REDD+, can be implemented on a larger scale (Börner et al. 2010). In the context of the Peruvian Amazon, as in most of Latin America, the situation is one in which informal rights are often asserted over any legalized property rights. Legal frameworks would seem to be of little significance, as observed with expanding illegal artisanal gold mining by Swenson et al. (2011). This is probably also the case with other high-priced global commodities present in Peru such as oil, gas, and coca. In addition to the arguments above, conflict over tenure and uncertainty of compensation will further increase the costs of conserving the remaining Peruvian Amazon forests, suggesting to us that the overall actual costs are likely to be closer to our upper estimates (US\$68 million per year) than the US\$25 million per year estimate of the Peruvian government.

\section{CONCLUSIONS}

Based on transaction costs of US\$0.16 to $1.44 \mathrm{ha}^{-1} \mathrm{yr}^{-1}$, (average US $\$ 0.73 \mathrm{ha}^{-1} \mathrm{yr}^{-1}$ ), our results suggest that the cost of implementing REDD+ in the Peruvian Amazon may be on the order of US $\$ 68$ million per annum. However, our estimates based on existing pilot projects are uncertain and likely to rise as, for example, the actual cost of achieving and monitoring emissions reduction through reduced deforestation and forest degradation, together with the required cobenefits, becomes known. Our results illustrate how these costs vary substantially from project to project and are quite uncertain. There is also a significant risk of actual costs being underestimated by governments and project developers because of inadequate project design, e.g., for implementation and monitoring activities, and how additionality is defined, e.g., estimation of expected emission reductions, with potentially significant negative consequences for the sustainability and viability of implemented projects. Importantly, implementation costs to reduce deforestation and forest degradation seem to be mainly influenced by the presence of activities aimed at local sustainability, remoteness of projects, and the type of 
institution implementing the project. However, more research is needed on the relationship between project costs and specific interventions to reduce deforestation and forest degradation. However, even with these first estimates, the cost of preserving existing intact forests in the Peruvian Amazon may have been underestimated.

Responses to this article can be read online at: http://www.ecologyandsociety.org/issues/responses. php/5239

\section{Acknowledgments:}

We are grateful to the funding provided by the Ecosystem Services for Poverty Alleviation (ESPA) research programme (grant no. NE/G00840X/1) of the UK Natural Environment Research Council (NERC), the Economic \& Social Research Council (ESRC), and the Department for International Development (DfID). We also acknowledge the financial support of the Centre for Climate Change Economics and Policy (CCCEP), which is funded by the UK's Economic and Social Research Council (ESRC). We thank the Instituto de Investigacion de la Amazonia Peruana (IIAP) and its staff for support. Thanks are due to all the contributors of information from different Peruvian and international organizations. We also acknowledge the helpful comments of the editor and anonymous reviewers.

\section{LITERATURE CITED}

Adams, W. M., R. Aveling, D. Brockington, B. Dickson, J. Elliott, J. Hutton, D. Roe, B. Vira, and W. Wolmer. 2004. Biodiversity conservation and the eradication of poverty. Science 306:1146-1149.

Amazon Conservation Association (ACA) and Asociación para la Conservación de la Cuenca Amazónica (ACCA). 2008. Los Amigos Conservation Concession. ACA, Washington, D. C., USA.

Angelsen, A., editor. 2008. Moving ahead with REDD: issues, options and implications. CIFOR, Bogor, Indonesia.

Angelsen, A., M. Brockhaus, M. Kanninen, E. Sills, W. D. Sunderlin, and S. Wertz-Kanounnikof, editors. 2009. Realising REDD+: national strategy and policy options. CIFOR, Bogor, Indonesia.

Anke, H., G. C. Zeri, J. Dietz, A. Freibauer, M. Hüttner, M. Jung, D. Mollicone, and M. Scheffler. 2008. Emissions and removals from land-use, land use change and forestry activities in a post-Kyoto regime - quantitative analysis of a framework for reducing deforestation. Nr. 26, FKZ 20642 100. Öko-Institut e.V., ECOFYS GmbH, Max-Planck Institut für Biogeochemie, Jena, Germany.
Armas, A., J. Börner, M. Tito, L. Díaz, S. C. Tapia-Coral, S. Wunder, L. Reymond, and N. Nascimento. 2009. Pagos por Servicios Ambientales para la conservación de bosques en la Amazonía peruana: Un análisis de viabilidad. Servicio Nacional de Áreas Naturales Protegidas (SERNANP), Lima, Peru.

Asner, G. 2009. Tropical forest carbon assessment: integrating satellite and airborne mapping approaches. Environmental Research Letters 4:034009. http://dx.doi.org/10.1088/1748-9326/4/3/034009

Asquith, N. M., M. T. Vargas Ríos, and J. Smith. 2002. Can forest-protection carbon projects improve rural livelihoods? Analysis of the Noel Kempff Mercado Climate Action Project, Bolivia. Mitigation and Adaptation Strategies for Global Change 7:323-337. http://dx.doi.org/10.1023/A:1024712424319

Baker, T. R., J. P. G. Jones, O. R. Rendón Thompson, R. M. Román Cuesta, D. Del Castillo, I. Chan Aguilar, J. Torres, and J. R. Healey. 2010. How can ecologists help realise the potential of payments for carbon in tropical forest countries? Journal of Applied Ecology 47(6):1159-1165. http://dx.doi. org/10.1111/j.1365-2664.2010.01885.x

Balmford, A., K. J. Gaston, S. Blyth, A. James, and V. Kapos. 2003. Global variation in terrestrial conservation costs, conservation benefits, and unmet conservation needs. Proceedings of the National Academy of Sciences 100 (3):1046-1050. http://dx.doi.org/10.1073/pnas.0236945100

Börner, J., and S. Wunder. 2008. Paying for avoided deforestation in the Brazilian Amazon: from cost assessment to scheme design. International Forestry Review 10 (3):496-511. http://dx.doi.org/10.1505/ifor.10.3.496

Börner, J., S. Wunder, S. Wertz-Kanounnikoff, M. Rügnitz Tito, L. Pereira, and N. Nascimento. 2010. Direct conservation payments in the Brazilian Amazon: scope and equity implications. Ecological Economics 69:1272-1282. http://dx. doi.org/10.1016/j.ecolecon.2009.11.003

Böttcher, H., K. Eisbrenner, S. Fritz, G. Kindermann, F. Kraxner, I. McCallum, and M. Obersteiner. 2009. An assessment of monitoring requirements and costs of 'Reduced Emissions from Deforestation and Degradation'. Carbon Balance and Management 4(7). http://dx.doi.org/10.1186/1750-0680-4-7

Boucher, D. 2008. What REDD can do: the economics and development of Reducing Emissions from Deforestation and Forest Degradation. Draft for external review. Tropical Forest and Climate Initiative, Washington, D.C., USA.

Brown, S. 2005. Description of GEOMOD and application to the Noel Kempff project area. Cooperative agreement between Winrock International and the EPA ID\# CR 827293-01-0. Winrock International, Arlington, Virginia, USA. [online] URL: http://www.winrock.org/ecosystems/files/Product $\% 201 \%$ 20GEOMOD\%20to\%20NKMCAP.pdf 
Brown, S., M. Burnham, M. Delaney, M. Powell, R. Vaca, and A. Moreno. 2000. Issues and challenges for forest-based carbon-offset projects: a case study of the Noel Kempff Climate Action Project in Bolivia. Mitigation and Adaptation Strategies for Global Change 5:99-121. http://dx.doi. org/10.1023/A:1009620903231

Bruner, A. G., R. E. Gullison, and A. Balmford. 2004. Financial costs and shortfalls of managing and expanding protected-area systems in developing countries. Bioscience 54 (12):1119-1126. http://dx.doi.org/10.1641/0006-3568(2004) 054[1119:FCASOM]2.0.CO;2

Cacho, O., and L. Lipper. 2007. Abatement and transaction costs of carbon-sink projects involving smallholders. Fondazione Eni Enrico Mattei (FEEM) Working Paper No. 27. FEEMattei, Milan, Italy. http://dx.doi.org/10.2139/ $\underline{\text { ssrn. } 976400}$

Cacho, O. J., G. R. Marshall, and M. Milne. 2003. Smallholder agroforestry projects: potential for carbon sequestration and poverty alleviation. ESA Working Paper No. 03-06. Food and Agriculture Organization of the United Nations, Rome, Italy.

Cacho, O. J., G. R. Marshall, and M. Milne. 2005. Transaction and abatement costs of carbon-sink projects in developing countries. Environment and Development Economics 10:597-614. http://dx.doi.org/10.1017/S1355770X05002056

Chenost, C., Y. M. Gardette, J. Demenois, N. Grondard, M. Perrier, and M. Wemaëre. 2009. Bringing forest carbon projects to the market. UNEP/UNEP RISO Centre/ONF International/afd/ FFEM/BIO-CF/CF-World Bank.

Corbera, E., M. Estrada, and K. Brown. 2010. Reducing greenhouse gas emissions from deforestation and forest degradation in developing countries: revisiting the assumptions. Climatic Change 100:355-388. http://dx.doi. org/10.1007/s10584-009-9773-1

Densham, A., R. Czebiniak, D. Kessler, and R. Skar. 2009. Carbon scam: Noel Kempff Climate Action Project and the push for sub-national forest offsets. Sub-prime carbon brought to you by AEP, BP, and Pacificorp. Greenpeace International, Amsterdam, The Netherlands.

Ferraro, P. J. 2002. The local costs of establishing protected areas in low-income nations: Ranomafana National Park, Madagascar. Ecological Economics 43:261-275. http://dx. doi.org/10.1016/S0921-8009(02)00219-7

Finer, M., and M. Orta-Martínez. 2010. A second hydrocarbon boom threatens the Peruvian Amazon: trends, projections, and policy implications. Environmental Research Letters 5:014012. http://dx.doi.org/10.1088/1748-9326/5/1/014012

Global Forest Coalition (GFC) and the Commission on Environmental, Economic and Social Policies (CEESP) of IUCN. 2008. The hottest REDD issues: rights, equity, development, deforestation and governance by indigenous peoples and local communities. GFC, Asunción, Paraguay, and IUCN, Gland, Switzerland.

Grieg-Gran, M. 2006. The cost of avoiding deforestation. Report prepared for the Stern Review of the Economics of Climate Change. International Institute for Environment and Development, London, UK.

Hajek, F., M. J. Ventresca, J. Scriven, and A. Castro. 2011. Regime-building for REDD+: evidence from a cluster of local initiatives in south-eastern Peru. Environmental Science and Policy 14:201-215. http://dx.doi.org/10.1016/j.envsci.2010.12.007

Healey, J. R., C. Price, and J. Tay. 2000. The cost of carbon retention by reduced impact logging. Forest Ecology and Management 139(1-3):237-255. http://dx.doi.org/10.1016/ S0378-1127(00)00385-6

Howard, A. F., R. E. Rice, and R. E. Gullison. 1996. Simulated financial returns and selected environmental impacts from four alternative silvicultural prescriptions applied in the neotropics: a case study of the Chimanes Forest, Bolivia. Forest Ecology and Management 89:43-57. http://dx.doi. org/10.1016/S0378-1127(96)03867-4

Htun, N. Z., N. Mizoue, T. Kajisa, and S. Yoshida. 2010. Deforestation and forest degradation as measures of Popa Mountain Park (Myanmar) effectiveness. Environmental Conservation 36(3):218-224. http://dx.doi.org/10.1017/ $\underline{\mathrm{S} 0376892909990415}$

Intergovernmental Panel on Climate Change (IPCC). 2000. IPCC special report emissions scenarios: summary for policymakers. A Special Report of IPCC Working Group III. World Meteorological Organization and United Nations Environment Programme, Nairobi, Kenya.

Kindermann, G., M. Obersteiner, B. Sohngen, J. Sathaye, K. Andrasko, E. Rametsteiner, B. Schlamadinger, S. Wunder, and R. Beach. 2008. Global cost estimates of reducing carbon emissions through avoided deforestation. Proceedings of the National Academy of Sciences 105(30):10302-10307. http:// dx.doi.org/10.1073/pnas.0710616105

Mooney, S., S. Brown, and D. Shoch. 2004. Measurement and monitoring costs: influence of parcel contiguity, carbon variability, project size and timing of measurement events. Report to The Nature Conservancy, Conservation Partnership Agreement. Winrock International, Arlington, Virginia, USA.

Mosquera, C., M. L. Chávez, V.H. Pachas, and P. Moschella. 2009. Estudio diagnóstico de la actividad minera artesanal en Madre de Dios. Borrador Final de Trabajo. COOPERACCION/ Caritas Madre de Dios/ Conservation International, Lima, Peru. 
Nepstad, D., B. Soares-Filho, F. Merry, P. Moutinho, H. Oliveira Rodrigues, M. Bowman, S. Schwartzman, O. Almeida, and S. Rivero. 2007. The costs and benefits of reducing carbon emissions from deforestation and forest degradation in the Brazilian Amazon. The Woodshole Research Center, Falmouth, Massachusetts, USA.

Oestreicher, J. S., K. Benessaiah, M. C. Ruiz-Jaen, S. Sloan, K. Turner, J. Pelletier, B. Guay, K. E. Clark, D. G. Roche, M. Meiners, and C. Potvin. 2009. Avoiding deforestation in Panamanian protected areas: an analysis of protection effectiveness and implications for reducing emissions from deforestation and forest degradation. Global Environmental Change 19:279-291. http://dx.doi.org/10.1016/j. gloenvcha.2009.01.003

Pagarán a indígenas por la conservación de la Amazonía. 2009. El Comercio, 30 July.

Pagiola, S., and B. Bosquet. 2009. Estimating the costs of REDD at the country level. Forest Carbon Partnership Facility, World Bank, Washington, D.C., USA.

Painter, J. 2008. Peru aims for zero deforestation. BBC News, 7 December. [online] URL: http://news.bbc.co.uk/1/hi/world/ americas/7768226.stm

Pinedo-Vasquez, M., D. Zarin, and P. Jipp. 1992. Economic returns from forest conversion in the Peruvian Amazon. Ecological Economics 6:163-173. http://dx.doi.org/10.1016/0921-8009 (92)90011-G

Pistorius, T., C. B. Schmitt, D. Benick, and S. Entenmann. 2010. Greening REDD+: challenges and opportunities for forest biodiversity conservation. Policy Paper, University of Freiburg, Freiburg, Germany.

Potvin, C., B. Guay, and L. Pedroni. 2008. Is reducing emissions from deforestation financially feasible? A Panamanian case study. Climate Policy 8:23-40. http://dx.doi. org/10.3763/cpol.2007.0386

Rondon, X. J., D. L. Gorchov, and S. R. Elliott. 2010. Assessment of economic sustainability of the strip clearcutting system in the Peruvian Amazon. Forest Policy and Economics 12:340-348. http://dx.doi.org/10.1016/j.forpol.2010.02.004

Sommerville, M. M., J. P. G. Jones, and E. J. Milner-Gulland. 2009. A revised conceptual framework for payments for environmental services. Ecology and Society 14(2): 34. [online] URL: http://www.ecologyandsociety.org/vol14/iss2/ $\underline{\operatorname{art} 34 /}$

Sommerville, M. M., E. J. Milner-Gulland, and J. P. G. Jones. 2011. The challenge of monitoring biodiversity in payment for environmental service interventions. Biological Conservation 144(12):2832-2841. http://dx.doi.org/10.1016/ j.biocon.2011.07.036
Swenson, J. J., C. E. Carter, J.-C. Domec, and C. I. Delgado. 2011. Gold mining in the Peruvian Amazon: global prices, deforestation and mercury imports. PLOS ONE 6(4):e18875. http://dx.doi.org/10.1371/journal.pone.0018875

Thompson, M. C., M. Baruah, and E. R. Carr. 2011. Seeing REDD+ as a project of environmental governance. Environmental Science \& Policy 14:100-110. http://dx.doi. org/10.1016/j.envsci.2010.11.006

United Nations Environment Programme (UNEP) and Amazon Cooperation Treaty Organization (ACTO). 2009. Environment outlook in Amazonia: GEO Amazonia. UNEP, Nairobi, Kenya.

United Nations Framework Convention on Climate Change (UNFCCC). 2011. Report of the Conference of the Parties on its sixteenth session, held in Cancun from 29 November to 10 December 2010. FCCC/CP/2010/7/Add.1. Decision 1/CP.16. United Nations, Geneva, Switzerland.

van Kooten, G. C., A. J. Eagle, J. Manley, and T. Smolak. 2004. How costly are carbon offsets? A meta-analysis of carbon forest sinks. Environmental Science and Policy 7:239-251. http://dx.doi.org/10.1016/i.envsci.2004.05.006

Vera Diaz, M. C., and S. Schwartzman. 2005. Carbon offsets and land use in the Brazilian Amazon. Pages 93-98 in P. Moutinho and S. Schwartzman, editors. Tropical deforestation and climate change. Instituto de Pesquisa Ambiental da Amazônia (IPAM), Belém, Pará, Brazil, Environmental Defense, Washington, D.C., USA.

Verweij, P., M. Schouten, P. Van Beukering, J. Triana, K. Van der Leeuw, and S. Hess. 2009. Keeping the Amazon forests standing: a matter of values. WWF-Netherlands, Zeist, The Netherlands.

Viana, V., M. Grieg-Gran, R. Della Mea, and G. Ribenboim. 2009. The costs of REDD: lessons from Amazonas. International Institute for Environment and Development, London, UK.

White, D., and P. Minang. 2011. Estimating the opportunity costs of REDD+: a training manual. Version 1.3. World Bank, Washington, D.C., USA.

Wunder, S., and M. Alban. 2008. Decentralized payments for environmental services: the cases of Pimampiro and PROFAFOR in Ecuador. Ecological Economics 65:685-698. http://dx.doi.org/10.1016/j.ecolecon.2007.11.004 